\title{
Power, conflict and consensus building in Africa: Ideology revisited
}

\author{
Browne Onuoha*
}

\begin{abstract}
This paper interrogates and rejects the effectiveness of consensus building as a mechanism for conflict resolution in Africa. Drawing from the conflict/ consensus theoretical debates of the 1960s, the paper argues that because of the inherent character of power, and considering the nature of the state in Africa which is subordinated to private interests, the political leaders will not readily bend to consensus. Instead of consensus the paper suggests a reform of the state. But beyond the reform, the paper points out the compelling need for the development of a virile civil society and a corresponding need for the re-invention of a nationalist ideology both of which will induce as well as facilitate the relative autonomy of the state. Thereafter, a reformed state in Africa will be better placed to adequately manage power and conflict.
\end{abstract}

Dr Browne Onuoha is an Associate Professor in the Department of Political Science at the University of Lagos, Lagos, Nigeria. He is currently on an exchange programme at California State University, Sacramento, California, USA. 


\section{Introduction}

Consensus, though an old concept, has re-entered the lexicon of African political and conflict studies since the 1990s. Other related concepts making similar re-entry are peace-dialogue, peace-building and culture of peace. The sequence of their relationships may be like the riddle of whether the chicken or the egg came first. But it is safe to assume that a culture of peace certainly encourages consensus building. Our focus in this paper is on consensus building.

The concept of consensus building is supposed to represent a mechanism or an approach to be adopted towards resolving some of the many intractable conflicts that have bedevilled Africa, in some instances for over four decades. Consensus as a mechanism being advocated is rightly derivable from the formulations of conflict/consensus social theories which were dominant in the social sciences in the 1950s and 1960s.

As presently applied in Africa, consensus building seems to be a product of knowledge arising from researches carried out in conflict areas in Africa with the help of some United Nations agencies. Often international professional negotiators and mediators are recruited by governments or international agencies to be involved in the processes, including negotiations expected to lead to consensus. The mechanism was encouraged during the negotiations for peace at the end of some of the long civil wars in parts of Africa as in Liberia, Sierra Leone, Rwanda, Democratic Republic of the Congo (DRC), and Southern Sudan. Also, consensus is envisaged in the resolution of the on-going racial, ethnic, tribal or religious wars and conflicts in Sudan/Darfur, Somalia and Côte d'Ivoire. It is assumed that consensus building will provide the key to peace in these conflict areas, or at least provide the environment which will enable peace to be built.

In addition to its theoretical roots in conflict/consensus social theories, consensus building is said to adequately fit into several of the elements of the democratisation process evolving in Africa at the same time that these conflicts are escalating. Indeed, the number of non-governmental organisations 


\section{Browne Onuoha}

(NGOs) devoted to consensus advocacy in Africa has grown as a result of the prospect of evolving peace through the mechanism of consensus. Many of the organisations have attracted generous funding from international agencies to organise conferences, seminars and workshops, and carry out research into dialogue and consensus building programmes focusing on the conflict areas in Africa. In a place like Rwanda, aspects of the educational curriculum are said to have been re-designed with the aim of re-socialising the children and the youth so that they may begin to cultivate attitudes that may, at least in future, create the environment for consensus building in their society (Mwambari and Schaeffer 2008).

The purpose of this article is to scrutinise consensus advocacy, which for nearly twenty years (from the 1990s) has involved the organisation of conferences, seminars and workshops devoted to encouraging consensus building among groups in conflict areas in Africa. Our query derives from the conflict/ consensus social theories, but with emphasis on the interface between conflict/ consensus and the theory of power. The central argument of the paper is that the type of power struggle at the level of the state in Africa does not submit to consensus as a mechanism for resolving conflict. The paper is of the view that any arrangement and management of the dialogue and consensus mechanism in Africa which does not put the state at the centre, and therefore necessarily brings to the fore the structure of power in that particular society, will have very little chances of success. Most of the conflicts in Africa are politically motivated, even when they appear otherwise as when they seem to be religious. This is because, directly or indirectly, most of these conflicts result from the struggle for access to, control and management of political power. And when that is the case, consensus building becomes still-born.

The paper is done in three parts. The first part explores the two relevant concepts of conflict and consensus, and the theoretical debate about them which is drawn from Ralf Dahrendorf $(1965,1968)$; and our emphasis relates the debate to the theory of power. The second part analyses the import of power, conflict and consensus within the context of political rivalry and at the level of the state. The paper recounts that at the level of the state, political parties are dominant and remain the major objects of analysis; and that 
consistent with their character they do not bend to consensus. In the third part, the paper concludes that while the consensus/dialogue advocacy may not be misleading, the present approaches adopted by some governments, international agencies and NGOs will not achieve results. This is because these approaches are rather intellectual and academic, and are directed mainly at civil society organisations. Instead, the paper suggests that an attempt should be made to re-create the civil society as well as re-invent a nationalist ideology for Africa. Both of these steps will enhance the relative autonomy of the state, and prepare the political system to better manage power and conflict.

\section{Conflict, consensus and power}

Conflict may be viewed as a form of tension arising from mutually exclusive or opposing actions, thoughts, opinions, or feelings. It is evident when individuals or groups evaluate situations or pass judgments from different perspectives that stem from incompatible differences in their education, social background or socialisation, or knowledge of the issues in contest. Conflict often occurs when people or groups perceive that as a result of a disagreement there may be a threat to their interests. Conflicts may also arise from misinformation, stereotypes, prejudices, contradictory perceptions of justice, differing sociocultural traditions, personal beliefs or ideologies; and they are of many dimensions: racial, sectarian, ethnic, religious, ideological, cultural, economic, political, social, and others (Kriesberg 1973:1-57; Kriesberg 2006).

According to Dahrendorf (1965:135), conflict also involves manifest clashes between social forces as well as incompatible differences of objectives, such as a desire on the part of both contestants to attain what is available, wholly or in part, only to one of them. He conceptualises social conflict as the great creative and ever-present force that leads to change. He remarks that societies and social organisations are held together not by consensus (emphasis mine) but by constraint, not by universal agreement but by the coercion of some by others. Whatever is considered the 'value system' is mostly that of the ruling party and not that of the common people. At any given time, it is usually upheld by enforcement rather than by general acceptance. He identifies conflict, change and a third notion, constraint, as always going together: 'and as conflict 


\section{Browne Onuoha}

generates change, so constraint may be thought of as generating conflict. We assume that conflict is ubiquitous, since constraint is ubiquitous wherever human beings set up social organisations ... it is always the basis of constraint that is at issue in social conflict' (Dahrendorf 1968:127).

In politics, conflict most often arises during the struggle for access to, control and management of political power, or during the process of determining what, long ago, Harold Lasswell (1990) saw as the essence of politics, which is 'who gets what, when, how'. By logic of action, most conflicts often end up being political, because in most instances their mediation is through some form of 'politics' or public policy. Consensus advocacy is of the view that most conflicts can be resolved through consensus building.

In itself, consensus represents stability, harmony, equilibrium, the universal, or contrat social, said to embody a broad agreement which, while not necessarily all-embracing, does embrace the overwhelming majority, involving unity, identity and co-ordination (Dahrendorf 1968:125; Atkinson 1971:236-237).

Consensus refers to a collective opinion expressing acceptance of a 'middle ground' in an outstanding issue or policy of general importance. Thus, it is a position of 'no winner, no loser', 'no victor, no vanquished', or a 'give and take' situation in the African parlance, which may be employed, it is assumed, in the many intractable socio-political crises and conflicts in Africa.

Over time, political thinkers have been concerned about the issue of conflict, particularly when directly or indirectly related to the structure of power in the society in general.

Thomas Bernard (1983) attempted to capture much of the movement of these ideas, from the ancient to the modern theorists, in his comparative analysis of the consensus-conflict debate. In a comparison of seven pairs of theorists on each side of the conflict and consensus divide, Bernard identifies three levels at which there could be conflict/consensus: the human level, the level of the contemporary state of the society, and the ideal society level (Bernard 1983: 12-15). He analyses the position of each pair at those three levels in relation to the predominance of consensus or conflict, and provides a particularly 


\section{Power, conflict and consensus building in Africa: Ideology revisited}

rigorous comparative analysis of Parsons' and Dahrendorf's consensus and conflict theories respectively (Bernard 1983:30-186, 145-186).

In the debate, the preoccupation of the theorists was (1) how to reconcile conflict and consensus in relation to the enforcement of norms, rules, laws, punishment and sanctions; (2) how to connect the reconciliation with power, authority, policy and the state; and (3) how to reconcile both consensus and conflict at the three levels which he (Bernard) identified (Wrong 1979:89; Bernard 1983: 12-15, 145-225). And according to Dennis Wrong (1979:89), this problem of reconciliation underlined the formulations of the social theories which were employed in the consensus/conflict debate. Dahrendorf is credited with having pioneered the study, highlighting the conflict/consensus divide. This was in reaction at the time to the consensus/equilibrium system maintenance of Talcott Parsons' structural-functionalism (Dahrendorf 1965, 1968; Parsons 1964, 1966, 1968, 1971; Wrong 1979:89-92; Bernard 1983:145-186).

The conflict model views individual or group relationships in all structures of power as a struggle which demonstrates some form of an irreducible element of coercion wherever such power structures exist (emphasis mine). On the other hand, the consensus model emphasises the predominance of legitimate authority in the society (Wrong 1979:89-91), and sees power as depending 'overwhelmingly on a consensual element, specifically referring to the absence of the use of overt physical force ...' (Bernard 1983:153).

In his analysis, Dahrendorf (1968:173-174) remarks that the functioning of society means that norms regulate human conduct. This regulation is guaranteed by the incentive or threat of sanctions; and he argues that the possibility of imposing sanctions is the abstract core of all power. He goes on to add that established norms are nothing but ruling norms, that is, norms defended by the sanctioning agencies of society and those who control them. Wrong (1979:90) is of the view that this formulation is no different from Hobbes' insistence on law as the command of the sovereign, or Marx's statement that norms are dictated and enforced by the ruling class.

All these remarks emphasise the structure of power in the society, as well as the determination of the extent to which consensus or conflict is permitted. However, 


\section{Browne Onuoha}

according to Bernard, part of the problem of the debate centred round the very broad definitions which each theorist, especially Parsons and Dahrendorf, gave to consensus and conflict. Apart from the problem of definition, and their inability to reconcile consensus/conflict at the three levels of human nature, the contemporary state of the society, and the ideal society, both Parsons and Dahrendorf agree that their two theories represent 'two faces of society', that is, that both conflict and consensus exist in the same society (Bernard 1983: 179-186). And Bernard's conclusion therein is that the consensus/conflict debate is not an empirical debate and cannot be resolved through empirical investigation (Bernard 1983: 217).

Nevertheless, the emphasis in this paper is on the structure of power and on the fact that it is most often expressed at the level of 'the contemporary state of the society'. According to Bernard, what is important in examining the theories at the level of the contemporary state of the society is not the question whether there is more consensus or conflict, but the terminology used for the description of the society at the particular point in time (Bernard 1983:15-16). And in Africa the literature is unambiguously replete with terms like 'crisis', 'conflict', 'war', which are all interconnected with the structure and struggle for power (emphasis mine). As observed by Parsons himself (Bernard 1983:154-155), these situations, which attract overt and potential uses of force, do not accommodate consensus as a serious political option. The reason is not unrelated to the nature of political power itself, which happens to be central to most issues resulting in conflict, and which intrinsically resists consensus. For, as Thomas Weldon (1962:3) contends, 'we may all hold that rights given by the constitution are sacred (consensus) and still fight one another (political struggle/conflict) because we cannot agree as to what these rights are'. These undefined and unsettled areas (what these rights are), are areas of political ferment, where political power incarnates, and at times get expressed in the most coercively unguarded forms; and most often these may only be resolved within the boundaries of state power which do not readily bend to consensus.

In other words, there may be consensus on some fundamental issues like operating a federation instead of a unitary system of government; a presidential system of government in the place of the cabinet system of government; two 


\section{Power, conflict and consensus building in Africa: Ideology revisited}

instead of three terms in office; or democratic government instead of military dictatorship. But in a federation, for instance, there are questions about which states/regions are to be created, what the boundaries are to be between federal and state powers, and how tight or loose the federation should be. These questions are difficult to define and resolve. They constitute the issues and essence of political power, which most often are not readily subject to consensus. For instance, in the federal states of the DRC, Nigeria and Sudan, for nearly fifty years, it has been difficult to reach a consensus on how tight or loose the federations should be, or the boundaries between state and federal powers; or indeed whether or not there should be one federal government. The three countries have gone to war at different times to get these issues resolved. Also, allocation of resources or the spoils of office - the 'who gets what, when, how' issue - triggers crisis and conflict at various levels of the society. This is an area that has created stalemate in Côte d'Ivoire, and the crisis aftermath of general elections in Ethiopia (2005), Nigeria (2007), Kenya (2007) and Zimbabwe (2008).

Thus, as observed by Wrong while reviewing the conflict/consensus debate (1979:91), in social theory it is more helpful to view institutional order as an outcome of past and on-going political conflict than to use system theory that postulates an underlying consensus or a tendency towards integration as a way of measuring order in the society. Wrong (1979:91) points out that this insistence on the importance of political power and its inherent coercive and conflictual aspects was mostly influenced by the writings of Max Weber, and that it was a correction rightly introduced by Dahrendorf to the excessive emphasis on legitimate authority in consensus and system theory.

Related to the issue of power, there are a few basic questions that have been raised in the consensus debate: where do we locate the consensus; who are to be involved, included or indulged in building consensus; and what is the content of the consensus? (Bernard 1983:178) These questions are important, according to the arguments of the community power theorists of the $1960 \mathrm{~s}$ (Dahl 1961; Hunter 1963; Polsby 1966), because even if consensus were to be achieved it would be meaningless unless it involved those who 'make things 


\section{Browne Onuoha}

move' in the community or larger society. Answers to these queries emphasise the central question of power, and strengthen the argument that the dialectic of power frustrates consensus, particularly when those who wield power are put into proper (power) perspectives. This is because in order for consensus to be meaningful, it needs to involve those who wield power. It is at the point of 'wielding' that we also examine in the next section the anatomy of power, and demonstrate that in democracy those who most often wield power, the political parties, do not politically behave in ways that significantly concede to consensus. This is particularly the case in Africa since, as already indicated by Lasswell's study of decades ago, there are too little democratic leadership and too few democratic personalities (Lasswell 1967:108-110, 150-152). This character of undemocratic leadership is further confirmed by recent events and studies about the on-going democratisation processes in Africa (Ake 1994, 1996, 2000; Schraeder 2002; Murunga 2002; Joseph 1999; Ottaway 1999; Bratton and Van de Walle 1998; Chole and Ibrahim 1995).

It is also pertinent to observe that in any matter concerning consensus, the state in Africa is ever present and very critical. In one way or another, consensus takes place within state boundaries. Thus the consensus, to a larger or smaller extent, will require the democratic nature of the state to be fully actualised and sustained, even at the lowest levels of the society, whether community, traditional, ethnic or religious. And the most ubiquitous agent of the state is government (the government of the day). In present-day democracies in Africa, unlike in the days of military dictatorship, governments are run by political parties successful at the polls. Where this is the situation, it will be correct to argue that there is no consensus negotiated anywhere within the state which will not meet political parties as the foremost 'stakeholders', even when the issues in demand may appear manifestly non-political. This is the case in Somalia, the DRC, Uganda, Chad, Niger, Southern Sahara, Côte d'Ivoire, Kenya and Zimbabwe. In most of these areas, political parties or identified groups with political agendas are those involved in negotiations for consensus. Even when the issues are ethnic, religious, or socio-cultural, those sent to represent constituencies in negotiations for consensus are manifestly or latently political actors. Examples are the genocide in Rwanda (Mamdani 2002; Lemarchand 
2008); racial conflicts in Sudan/Darfur (Flint and De Waal 2008); the religious riots in Jos, Plateau State, Nigeria (Banjo 2009); and the Niger Delta crisis also in Nigeria.

More fundamentally, in each conflict area, the structure of the political party goes furthest to the grassroots and it is therefore best organised to respond to any negotiations for consensus. Therefore, in each case the party is the most visible organisation, even when the issues involved appear non-political. Thus, in spite of consensus, the members of political parties will not ignore the fact that their parties are struggling for political power, with all the inherent characteristics of political power. This largely explains why most conflicts in Africa seem intractable. Somalia, Sudan/Darfur, Chad, Côte d'Ivoire, and the Great Lakes Region (Lemarchand 2008) are apt examples.

Thus, in many political crises since political independence in the 1960s in most parts of Africa, access to, and control and management of power for the purposes of resource allocation have remained the central issues under contest. Other factors such as tribalism or ethnicity (pluralism) have also been identified. But these latter factors manifested in the events of struggle for political power (emphasis mine) (Sklar 1966; Lloyd 1970; Ekeh 1975; Markovitz 1977; Nnoli 1978; Young 1993). Therefore, the frequent manifestations of crises and conflicts around the power nexus tend to pose constraints, and at times frustration about consensus building, and thus limit its success as a mechanism for peace. As suggested above, the limitations to consensus are directly related to the structure and dynamics of power, which are explored immediately below.

\section{Anatomy of power and the limits of consensus}

Studies indicate that the contest for power has a dynamic that differs from that of other social phenomena. In political studies, political power is the ultimate state craft, and its capture is the most consuming preoccupation of political actors. Several definitions are provided of what political power is, and most of them focus on its influence, force, coercion, manipulation, persuasion, and similar attributes. Other diverse features, types, categories, dimensions and 


\section{Browne Onuoha}

complexities of power are also provided and examined by scholars (Lasswell 1967; Lasswell and Kaplan 1976; Wrong 1979; Gerth and Mills 1978; Dahl 1970; Galbraith 1985).

In their definition, Lasswell and Kaplan (1976:85) view power as 'the capacity of an individual or group of individuals to modify the conduct of other individuals or groups in the manner which they desire ... the political process is the shaping, distribution and exercise of power ... What men seek in their political negotiations is power .... In a similar characterisation, Mills (1964:171) observes that 'all politics is struggle for power; (and) the ultimate kind of power is violence'. Weber has a similar definition of power as 'the possibility of imposing one's will upon the behaviour of other persons' (Gerth and Mills 1978:80). All these characterisations are similar to an observation by Robert Dahl $(1970: 32,15)$ about the complex and awesome nature of power in his remarks that:

Nothing is more likely to lead to bad political strategies than to misunderstand 'power', to misperceive 'the power structure'; for to be misled about 'power' is to be misled about the prospects and means of stability, change, and revolution. The graveyard of history is strewn with the corpses of reformers who failed not only because of the forces arrayed against them but because the pictures in their minds about power and influence were simplistic and inaccurate.

These features of power identified by scholars show the extent to which power and consensus may be irreconcilable. This is especially so in Africa where several states have been rated as weak.

Lord Acton identified other characteristics of power, warning against its ultimate, centralising and total nature, and showing how these foreclose consensus. This is contained in his widely quoted statement: 'power tends to corrupt, and absolute power corrupts absolutely' (Darlberg-Acton 1988:519521; Hill 2000:300-302). According to Acton, 'great men are almost always bad men, even when they exercise influence and not authority ... among all the causes which degrade and demoralise men, power is the most constant and the most active' (Darlberg-Acton 1988:519-521; Hill 2000:300-302; Dahl 1970:15). 


\section{Power, conflict and consensus building in Africa: Ideology revisited}

Robert Michels (1968:342-356) in his study stresses that political parties make the winning of power by elections imperative as well as compelling through the oligarchical nature of their structure and organisation. In Africa such electoral victory is often viewed as a 'winner-takes-all' situation. And by the intrinsic characteristics of power identified, such a winner situation may not at the same time accommodate consensus in the control and management of political power. Also, in a rather bewildering expression, emphasising the critical need for political parties to win and maintain power, Weber states that 'parties live in the house of power' (Gerth and Mills 1978:81). Considering all the attributes of power, Weber's 'house of power' is more or less a 'castle of power', especially in many parts of Africa. And by implication, a 'castle of power' which permits 20 or 30 years of rule to one man does not have provision for consensus. This approximates the scenario of power structure and power struggle in Africa until the recent democratisation process as mentioned below.

In his own contribution, Dahrendorf (1968:205) argues that the structure of power which exists in all human societies explains not only how change originates and what direction it takes, but also why it is necessary. He is of the view that 'power always implies non-power and therefore resistance. The dialectic of power and resistance is the motive force of history ... Power produces conflict, and conflict between antagonistic interests gives lasting expression to the fundamental uncertainty of human existence ...' (Dahrendorf 1968:227). Power underlies conflict as well as underpins class differences in every human society (Dahrendorf 1968:227, 1967:17). If we may relate Dahrendorf's formulations to consensus in African politics, he is arguing that power implies inherent imbalance or lack of balance. And if there is imbalance or lack of balance, there will be little or no urge for those holding the power to commit time to consensus building, unless there is a meaningful threat to their control of power. This is also the political sociology of 'winnertakes-all' politics in Africa, particularly because, as we will examine shortly below, in Africa power does not yet check power. In other words, the emphasis drawn from the formulations of the scholars is that the inherently awesome, centralising, possessive, and coercive characteristics of power do not allow consensus building as a meaningful way of resolving political conflict in Africa. 


\section{Browne Onuoha}

While there are positive attributes of power as observed by Lasswell (1967:9), it is necessary that the elements, dialectic, and dynamics of power be adequately understood in order to appreciate why consensus may not be sustainable as means of resolving conflicts among political contenders in Africa. This is the argument of the next section of the paper.

\section{Power, politics and consensus building in Africa}

John Galbraith (1985:19-25, 51-64) identifies three sources from which power is acquired: personality, property, and organisation. All sources of power are interconnected, and all three find most effective expression in Galbraith's analysis of organisation and the state. It is within that analysis that the examination of political parties and power becomes appropriate (Galbraith 1985:65-80, 140-152). In his review Galbraith observes that: 'the modern state unites within its structures all three sources of power ... It has manifest access to all three instruments of enforcement, and these have increased over the years in their absolute and relative importance within the formal structure of government' (Galbraith 1985:140-141).

In a democratic order, the structure of power and instruments of enforcement of the powers of the state are under the control of the ruling political party. This is in spite of all the checks and balances in government. In Africa, with the degree of control that is prevalent, calls for consensus will be 'too simplistic and inaccurate' (Dahl 1970:15). Instead of consensus, Galbraith (1985:81) argues that control of power can only come about through a countering power. Lord Acton, whom we quoted earlier, expresses a similar view that it is only with power that power can be put in check (Darlberg-Acton 1988:521).

As we shall argue shortly, because the state in Africa lacks relative autonomy, state power is captured and seized by a dominant ruling interest. Accordingly, it becomes difficult for power to effectively check power, because the dominant interest that captures the state ensures that it has a monopoly of state power, which hitherto in Africa has been near absolute and overwhelming ('the winner-takes-all' situation/politics). However in more recent times, prospects for challenges to power, though not yet effective, have been increasing with the 


\section{Power, conflict and consensus building in Africa: Ideology revisited}

emergence of democratisation processes of the 1990s in Africa (Bratton and Van de Walle 1998; Onuoha and Fadakinte 2002; Muranga 2002).

Put differently, it may be argued that countering power with power, as argued by Galbraith, theoretically presupposes that the state possesses the known attributes of 'relative autonomy', and plays the role of an arbiter among group interests within the society (Gramsci 1971; Showstack 1987). ${ }^{1}$ But states in Africa lack these attributes (Ake 1985, 1994). The pioneer political leaders who struggled for political independence from the colonial masters in the 1960s appropriated the benefits of political independence, especially through the use of political power to expropriate economic resources, at the same time deploying these resources of the state to consolidate their grip on political power. This trend of thought is an extensive discourse of politics in Africa in the social sciences literature, and has provided a fundamental interpretation of the crises and conflicts in Africa from the 1960s to date (Carter 1966; Rotberg and Mazrui 1970; Lofchie 1971; Markovitz 1977; Ake 1981, 1994; Jackson and Rosberg 1982; Rothchild and Chazan 1988; Fatton 1992; Bayart 1993; Bayart, Ellis and Hibou 1999; Joseph 1991; Joseph 1999). Indeed, the struggle for political power has intensified with the years, attracting a higher premium for every new set of struggle, like during elections, formation of new governments, or even struggle for citizenship (Ake 1994, 1996, 2000; Joseph 1999; Ottaway 1999; Schraeder 2002; Lemarchand 2008).

According to Claude Ake, a more disturbing aspect of this development is that by the beginning of the twenty first century, African political leaders had nothing meaningful in their agenda to reform this character of the state, a

1 'Relative autonomy' raises the question about the extent to which a state under capitalism may be relatively free from domination by the various competing interests within the system. The formulation assumes that no state may be absolutely free from domination. The fundamental concern is that being relatively autonomous is necessary for the state to be neutral, an arbiter, an umpire, and not unduly favouring one particular interest or the other, in enforcing the laws, and thereby defining the extent to which the rule of law may be said to apply. The issue of 'Relative autonomy' of the state, deriving from Antonio Gramsci's formulations, was a stimulating scholarly debate among radical scholars in Europe between the late 1960s and middle of the 1980s, demonstrated in the robust engagements of Nicos Poulantzas and Ralph Miliband. African scholars of radical bent extensively employed the analysis to examine the problem of the state in Africa. 


\section{Browne Onuoha}

reform which would enhance the state's character of 'relative autonomy' and mediation, and which would enable it to ensure the rule of law and impartially resolve conflicts among the dominant interests in the entire society (Ake 1994:8-9). The reform may not meaningfully take place now, because those controlling the state are beneficiaries of the present character of the state, and are aware of the enormous power of the state under their control. Under such a power imbalance, consensus will not be attractive to those in dominant control of the instruments of state power.

Instead of consensus, there may be party coalitions and alliances of senior and junior partners determined by relative successes at the polls, or ethnic compacts in some cases (Schraeder 2004:106-110). Indeed, in the analyses of power/consensus relationships, a hidden reality is that the demand for consensus arises from the point at which power is assumed to have failed or is failing. In other words, a strong demand for consensus may be an indication that those wielding power are getting weak, and losing control of power, and contenders getting stronger and more confident to challenge power by asking for consensus (Wrong 1979:88).

In addition to the problem of power, there is also the issue of justice in the exercise of political power - which may not be left out in cases of conflict and consensus in Africa. Studies of justice explain the persistent demand for justice as a factor in most conflicts, including those in Africa (Rawls 1971). Thus, even if consensus and stability were regarded as desirable, forms of injustice like corruption, oppression, manifest deprivations, and other forms of violation of human rights, may instigate long-drawn struggles for freedom. And unless the

offending issues are resolved, no amount of advocacy or organisation will allow room for consensus building. In his analysis of the subject, Rawls (1971:4-55) stresses that there must be a measure of agreement on what is social justice for there to be a viable human community. He holds the state (the African state in this case) responsible for the provision of the ideal political environment for the enforcement of justice in the rest of society. In a related study, Sen (2004:338-350) argues that these rights include welfare rights, which stand to reason, and are clearly needed, even if the obligation of the state in meeting these rights is an imperfect one. The failure of African leaders to fulfil these 
obligations, as well as uphold other larger issues of justice, gives rise to most of the crises and conflicts which are at present perplexing Africa. And with such disregard for obligations, consensus and peacebuilding may not be achieved. In the circumstances, consensus, as much as it is desirable, may be sought elsewhere in the civil society. This is the argument in our conclusion.

\section{Conclusion: The Civil Society Ideology and consensus building}

This paper has argued that in Africa, consensus building among political actors may not succeed in most circumstances involving the struggle for power. It is our suggestion that there is a need to adequately understand the theory of power, as it is power that most often underpins conflicts, in order to appreciate the limitations of consensus building in Africa. We further suggest that rather than advocate consensus building, which may not be attainable under the dialectic of political power, there should be an endeavour to reform the state, and above all, build a virile civil society with a dominant nationalist ideology.

Civil society is comprised of various interest and pressure groups, including non-governmental organisations, who in themselves constitute the national sovereign, and whose interactions most of the time are 'outside the state', and on the basis of trust and consensus (Seligman 1992; Harberson, Rothchild and Chazan 1994; Hall 1995). The consensus includes their recognised role as vanguard, the last ditch of protection for human rights, and as promoters of democracy and good governance. According to Lipset (1994:7), private associations (the civil society) are sources of restrictions on the government and serve as major channels for involving people in politics; they are also mechanisms for creating and maintaining the consensus necessary for a democratic order. In other words, because the civil society does not struggle for political power, it is easier for members to function by persuasion, cooperation and compromise, and to become oriented towards consensus in their interactions (Atkinson 1971:236-239). However, in Africa this may not always be the case, because there are times when 'politics' intrudes into and 


\section{Browne Onuoha}

bogs down the activities of civil society groups. Nevertheless, the features of a stronger civil society make consensus building relatively easier to achieve.

At the same time, it gives cause for grave concern that currently there is no serious endeavour by African governments, through investment in policies, to consciously build the civil society in Africa. Such policies should include good governance first and foremost. Also to be promoted are youth education programmes containing special national values planned and implemented as socialisation processes in schools, youth organisation/association centres, churches, mosques, community centres and professional associations. In the 1990s civil society organisations were active and indeed crucial during the early years of democratic transition in Africa (Olukoshi 1997; Bratton and Van de Walle 1998; Makumbe 1998). But apparently they lost steam after the initial elections that introduced foundation democratic governments at the time. With some exceptions, civil society in Africa seems to be disappointingly weak. Also there is little awareness among the citizens of the relevance of the civil society, and no evidence of their reliance on it as a force that can bring the political actors under control - the type of control which, according to Lipset (1994:7), civil societies exercised in developed countries at that time in history, as watch dog and the ultimate sovereign.

However, it is important to emphasise that there can be no virile civil society without an ideology: a world view, a guide, a value system, a national spirit around which all societal actions revolve; which gives strength, meaning, direction, and interpretation of the world to the whole society (Mannheim 1976; Apter 1965).

According to Friedrich and Brzezinski (1964:71-96), ideology is 'the general system of beliefs held in common by the members of a collectivity; that is ... it is a system of ideas and values which are oriented towards the evaluative integration of the collectivity and of the situation in which they are placed, the processes by which they have developed to their given state, the goals towards which the members are collectively oriented, and their relation to the future course of events' (Friedrich and Brzezinski 1964:88). Also confirming the centrality of ideology to national consciousness, direction and philosophy, 
Weldon (1962:7) observes that inevitably ... unless disputants are agreed on something quite different, namely an abstract political principle (ideology), they will, and can lead to no conclusion'.

The issue of ideology and its role in national development is a tested and canvassed subject. In Africa it was an advocated ingredient of development in some countries from the 1960s to the 1980s. Its inclusion in development thinking began to decline with the economic recession of the 1980s, especially when it failed to advance development in those countries which introduced such ideological content and guide to their development efforts, in particular, Nyerere's Tanzania, and some Marxist-oriented economies in Africa (Young 1982; Hyden 1983; Lubeck 1987; Keller and Rothchild 1987; Cohen and Gouldbourne 1991; Hughes 1992; Apter and Rosberg 1994).

Nevertheless, ideology is being reconsidered in the African context because of the quest for a positive, creative, cohesive, and aggregative value system, the type achieved by the Asian Tigers, reputed to be rooted in the values of Confucianism (World Bank 1995; Hill 1997). It is a value system which insists on nationalism, moral values and thrift in the macroeconomic principles of management, openness and equity; thrift/savings and austerity instead of the profligacy and the high level of corruption prevalent in Africa.

The use of ideology in this discussion is deliberately conceived to include all efforts to internalise constructive and guiding principles in the peoples' productive capacities which will enable them to take control of their environment and develop it with their own knowledge and expertise. Here we are suggesting nationalism to be the ruling ideology for African states.

Nationalism refers to collective feelings and identities, emotions, behaviour, norms, and values which develop and elevate a single spirit of nationhood above all other elements and characteristics. Nationalism involves shared beliefs, characteristics, and a common goal as one people. While there may be sub-cultures, there remains a common overarching cultural value which binds the people of a single nationhood; and their attitudes, beliefs and behaviour become influenced by that common cultural value. Nationalism is usually evolved and built by nation-builders who emerge with the values. The values 


\section{Browne Onuoha}

of the emergent leadership usually become higher and dominant, and are accepted by the majority of the people at the time. In turn, both the leadership and the people stand to maintain and defend the values. In many instances this formation process is related to the idea of building hegemony, and may be studied under that rubric (Gramsci 1971; Gray 1977; Joseph 2002).

However, critical to the success of national ideology is that the ideology necessarily has to be indigenous (Kedourie 1970; Nyerere 1982; Low 1982; Hyden 1983; Neuberger 1986). In a recent paper emphasising indigenousness and autonomy, William Easterly (2007) argues that instead of the 'developmentalist ideology' of the World Bank and the International Monetary Fund, Africans should develop a homegrown path to success, and ignore the 'developmentalists' like the Asians always did in their path to development. But in Africa, one of the weaknesses of previous attempts at building the ideology of development was that none of the ideologies was 'homegrown', or sufficiently indigenous to become a national guide. Also, they were not rooted in the culture.

The indications are that without a common ruling ideology, consensus even at the level of the civil society becomes very difficult. If there were a common ideology, even if consensus were not built, political parties could go into accords, coalitions or alliances. In such cases, politically, the preoccupation will be the effort to keep coalition agreements. But political parties in Africa most often do not keep such agreements. The coalitions break down not because consensus was not built, but because the exploitative and accumulative tendencies of most African leaders do not allow them to respect agreements entered into with other political leaders. Certainly, political leaders who cannot keep coalition agreements will be the least disposed to consensus building.

Therefore consensus, strictly speaking, lies outside the context and exercise of party politics. Instead, it is the consensus within the civil society which influences the behaviour and actions of the parties, and which acts as a check on them, and makes them invoke a nationalist ideology as a recourse in cases which otherwise would bring conflict. This is further confirmed by Lipset, referring to Tocqueville's observation that voluntary associations limit the 
central power, create new and autonomous centres of power to compete with it, and help to train potential opposition leaders in political skills (Lipset 1994:8).

In conclusion, it is pertinent to observe that at present, the issue of building an ideology is totally missing from the agendas of most African states, and worse still, missing from the research focus in African higher institutions and research centres. There is little evidence of current research on ideology in African institutions and in major current publications on that subject matter.

It is our view in this paper that there is need for research to be directed towards inventing an ideology of nationalism which will guide political party activities, national politics and all aspects of public policy, including the preservation of socio-cultural values. If a nationalist ideology is built, it will support the rule of law, constitutionalism, justice, accountability and good governance which will prevail at the level of the state, while at the level of the civil society, consensus building will still remain under the guiding influence of the same ideology. Of course this recognises the interconnection known to exist between the state and civil society as well as the fact that both reinforce each other.

\section{Sources}

Ake, Claude 1981. A political economy of Africa. Harlow, Essex, Longman Group.

Ake, Claude 1994. Democratization and disempowerment in Africa. CASS (Centre for Advanced Social Sciences) Occasional Mono No.1. Port Harcourt, Malthouse Press.

Ake, Claude 1996. Democracy and development in Africa. Washington, D.C., Brookings Institute.

Ake, Claude 2000. The feasibility of democracy in Africa. Dakar, CODESRIA (Council for the Development of Social Science Research in Africa).

Apter, David 1965. Politics of modernization. Chicago, University of Chicago Press.

Apter, David and Carl G. Rosberg eds. 1994. Political development and the new realism in Sub-Saharan Africa. Charlottesville, University Press of Virginia.

Atkinson, Dick 1971. Orthodox consensus and radical alternatives: A study of sociological theory. London, Heinemann Educational Books.

Banjo, Adewale O. 2009. The Tiv-Jukun conflict, the state and human rights violations in central Nigeria. Paper presented at the International Conference on Race, Religion and Ethnic Relations in Africa/Diaspora: Creating Peace and Justice Dialogues, organised by the Centre for Africa Peace and Conflict Resolution (CAPCR), California State University, 


\section{Browne Onuoha}

Sacramento, and the College of Health and Human Services in Collaboration with Pan African Studies Program. 30 April-2 May 2009.

Bayart, Jean-Francois 1993. The state in Africa: The politics of the belly. London, Longman.

Bayart, Jean-Francois, Stephen Ellis and Beatrice Hibou 1999. The criminalization of the state in Africa. Oxford, James Currey.

Bernard, Thomas J. 1983. The consensus-conflict debate: Form and content in social theory. New York, Columbia University Press.

Bratton, Michael and Nicholas van de Walle 1998. Democratic transition in Africa: Regime transitions in comparative perspective. Cambridge, Cambridge University Press.

Carter, Gwendolen M. ed. 1966. Politics in Africa: 7 cases. New York, Harcourt Brace and World Inc.

Chole, Eshetu and Jibrin Ibrahim eds. 1995. Democratization processes in Africa: Problems and prospects. Dakar, CODESRIA.

Cohen, Robin and Harry Gouldbourne eds.1991. Democracy and socialism in Africa. Boulder, Westview.

Dahl, Robert A. 1961. Who governs? Democracy and power in an American city. New Haven and London, Yale University Press.

Dahl, Robert A. 1970. Modern political analysis. Englewood Cliffs, Prentice-Hall.

Dahrendorf, Ralf 1965. Class and class conflict in industrial society. Stanford, CA, Stanford University Press.

Dahrendorf, Ralf 1967. Conflict after class: New perspectives on the theory of social and political conflict. The Third Noel Buxton Lecture of the University of Essex - 2 March 1967. London and Colchester, Longmans.

Dahrendorf, Ralf 1968. Essays in the theory of society. Stanford, CA, Stanford University Press.

Darlberg-Acton, John E.E. 1988. Selected writings of Lord Acton Vol. III. Essays in religion, politics and morality. Edited by J. Rufus Fears. Indianapolis, Liberty Classics.

Easterly, William 2007. The ideology of development. Foreign Policy, July/August. Available from: <www.nyu.edu/fas/institute/Easterly/File/FP_Article0707.pdf> [Accessed 15 August 2009].

Ekeh, Peter 1975. Colonialism and the two publics in Africa: A theoretical statement. Comparative Studies in Society and History, 17 (1), pp. 91-112.

Fatton, Robert 1992. Predatory rule: State and civil society in Africa. Boulder, Lynne Rienner.

Flint, Julie and Alex de Waal 2008. Darfur: A new history of a long war. Revised and updated. London and New York, Zed Books.

Friedrich, Carl J. and Zbigniew Brzezinski 1964. Totalitarian dictatorship and autocracy. New York and London, Frederick A. Praeger Publisher.

Galbraith, John K. 1985. The anatomy of power. Boston, Corgi Books. 


\section{Power, conflict and consensus building in Africa: Ideology revisited}

Gerth, Hans H. and C. Wright Mills 1978. From Max Weber: Essays in sociology. New York, Oxford University Press.

Gramsci, Antonio 1971. Selections from the prison notes. Translated by Quintin Hoare and edited by Geoffrey Nowell Smith. London, Lawrence and Wishart.

Gray, Robert 1977. Bourgeois hegemony in Victorian Britain. In: Bloomfield, J. ed. Class, hegemony and party. London, Lawrence and Wishart.

Hall, John 1995. Civil society: Theory, history, comparison. London, Polity Press.

Harberson, John W., Donald Rothchild and Naomi Chazan 1994. Civil society and state in Africa. London, Lynne Rienner.

Hill, Hal 1997. Towards a political economy explanation of rapid growth in Association of Southeast Asian Nations (ASEAN): A survey and analysis. ASEAN Economic Bulletin, 14 (2), pp. 131-145.

Hill, Roland 2000. Lord Acton. New Haven and London, Yale University Press

Hughes, Arnold ed. 1992. Marxism's retreat from Africa. London, Frank Cass.

Hunter, Floyd 1963. Community power structure: A study of decision makers. New York, Anchor Books, Doubleday and Company.

Hyden, Goren 1983. Beyond Ujamaa in Tanzania: Underdevelopment and an uncaptured peasantry. Berkeley, University of California Press.

Jackson, Robert H. and Carl G. Rosberg 1982. Personal rule in Black Africa: Prince, autocrat, prophet, tyrant. Berkeley, University of California Press.

Joseph, Jonathan 2002. Hegemony: A realist analysis. London and New York, Routledge and Kegan Paul.

Joseph, Richard A. 1991. Democracy and prebendal politics in Nigeria: The rise and fall of the Second Republic. Ibadan, Spectrum Books.

Joseph, Richard A. ed. 1999. State, conflict and democracy in Africa. Boulder, Lynne Rienner.

Kedourie, Elie ed. 1970. Nationalism in Asia and Africa. New York, World Publishing Books.

Keller, Edmond J. and Donald Rothchild eds. 1987. Afromarxist regimes: Ideology and public policy. Boulder, Lynne Rienner.

Kriesberg, Louis 1973. The sociology of social conflicts. Englewood Cliffs, Prentice-Hall.

Kriesberg, Louis 2006. Constructive conflicts: From escalation to resolution. $3^{\text {rd }}$ ed. Lanham, Rowman and Littlefield.

Lasswell, Harold D. 1967. Power and personality. New York, The Viking Press.

Lasswell, Harold D. 1990. Politics: Who gets what, when, how. New York, Peter Smith Publisher.

Lasswell Harold D. and Abraham Kaplan 1976. Power and society: A framework for political inquiry. New Haven, Yale University Press. 


\section{Browne Onuoha}

Lemarchand, René 2008. The dynamics of violence in Central Africa. Philadelphia, University of Pennsylvania Press.

Lipset, Seymond M. 1994. The political man: The social bases of politics. Baltimore, The Johns Hopkins University Press.

Lloyd, Peter C. 1970. The ethnic background to the Nigerian crisis. In: Panter-Brick, S.K. ed. Nigerian politics and military rule: Prelude to the Nigerian civil war. London, The Athlone Press.

Lofchie, Michael ed. 1971. The state of the nations: Constraint on development in independent Africa. Berkeley, University of California Press.

Low, Anthony D. 1982. The Asian mirror to Tropical Africa's independence. In: Gifford, Prosser and Roger Louis eds. The transfer of power in Africa: Decolonization, 1940-1960. New Haven, Yale University Press.

Lubeck, Paul M. ed. 1987. African bourgeoisie: Capitalist development in Nigeria, Kenya and Ivory Coast. Boulder, Lynne Rienner.

Makumbe, John M.W. 1998. Is there a civil society in Africa? International Affairs, 74 (2), pp. 305-317.

Mamdani, Mahmood 2002. When victims become killers: Colonialism, nativism, and the genocide in Rwanda. Princeton and Oxford, Princeton University Press.

Mannheim, Karl 1976. Ideology and utopia: An introduction to the sociology of knowledge. London, Routledge and Kegan Paul.

Markovitz, Irving L. 1977. Power and class in Africa: An introduction to change and conflict in African politics. Englewood Cliffs, Prentice-Hall.

Michels, Robert 1968. Political parties: A sociological study of the oligarchical tendencies of modern democracy. New York, The Free Press.

Mills, C. Wright 1964. The power elite. New York, Oxford University Press.

Muranga, Godwin R. 2002. A critical look at Kenya's non-transition to democracy. Journal of Third World Studies, 19 (2), pp. 89-111.

Mwambari, David and Sarah Schaeffer 2008. Post-conflict education: The case of history curriculum in post-genocide Rwanda. Paper presented at the $17^{\text {th }}$ Annual Africa/Diaspora Conference on The African Youth in Africa and America: Bridging the Gaps, held at the California State University, Sacramento, University Union, 1-3 May 2008.

Neuberger, Benjamin 1986. National self-determination in postcolonial Africa. Boulder, Lynne Rienner.

Nnoli, Okwudiba 1978. Ethnic politics in Nigeria. Enugu, Fourth Dimension Publishers.

Nyerere, Julius 1972. UJAMAA: Essays on socialism. Dar es Salaam, Oxford University Press. 


\section{Power, conflict and consensus building in Africa: Ideology revisited}

Olukoshi, Bayo. 1997. Associational life. In: Diamond, Larry, Anthony Kirk-Greene and Oyeleye Oyediran eds. Transition without end: Nigerian politics and civil society under Babangida. Ibadan, Vintage Publishers.

Onuoha, Browne and Mojibayo Fadakinte 2002. Transition politics in Nigeria, 1970-1999. Lagos and Oxford, Malthouse Publishers.

Ottaway, Marina 1999. Africa's new leaders: Democracy or state reconstruction? Washington, D.C., Carnegie Endowment for International Peace.

Parsons, Talcott 1964. The social system. New York, The Free Press/Macmillan.

Parsons, Talcott 1966. Societies: Evolutionary and comparative perspectives. Englewood Cliffs, Prentice-Hall.

Parsons, Talcott 1968. The structure of social action. New York, The Free Press.

Parsons, Talcott 1971. The system of modern societies. Englewood Cliffs, Prentice-Hall.

Polsby, Nelson 1966. Community power and political theory. New Haven and London, Yale University Press.

Rawls, John 1971. A theory of justice. Cambridge, Harvard University Press.

Rotberg, Robert I. and Ali A. Mazrui eds. 1970. Protest and power in Black Africa. Oxford, Oxford University Press.

Rothchild, Donald and Naomi Chazan eds. 1988. The precarious balance: State and society in Africa. Boulder, Westview.

Schraeder, Peter J. 2004. African politics and society: A mosaic in transformation. Belmont, Thomson Wadsworth.

Schraeder, Peter J. ed. 2002. Exporting democracy: Rhetoric vs reality. Boulder, Lynne Rienner.

Seligman, Adam B. 1992. The idea of civil society. New York, The Free Press.

Sen, Amartya 2004. Elements of a theory of human rights. Philosophy and Public Affairs, 32 (4), pp. 315-356.

Showstack, Sasson A. 1987. Gramsci’s politics. London, Hutchinson Publishing.

Sklar, Richard L.1966. Nigerian politics: The ordeal of Chief Awolowo 1960-65. In: Carter 1966.

Weldon, Thomas D. 1962. State and morals: A study of political conflict. Re-issued with foreword. London, John Murray.

World Bank 1995. The East Asian miracle, economic growth and public policy. New York. Oxford University Press.

Wrong, Dennis H. 1979. Power: Its forms, bases and uses. New York, Harper and Row.

Young, Crawford 1982. Ideology and development in Africa. New Haven, Yale University Press.

Young, Crawford 1993. The politics of cultural pluralism. Madison, University of Wisconsin Press. 